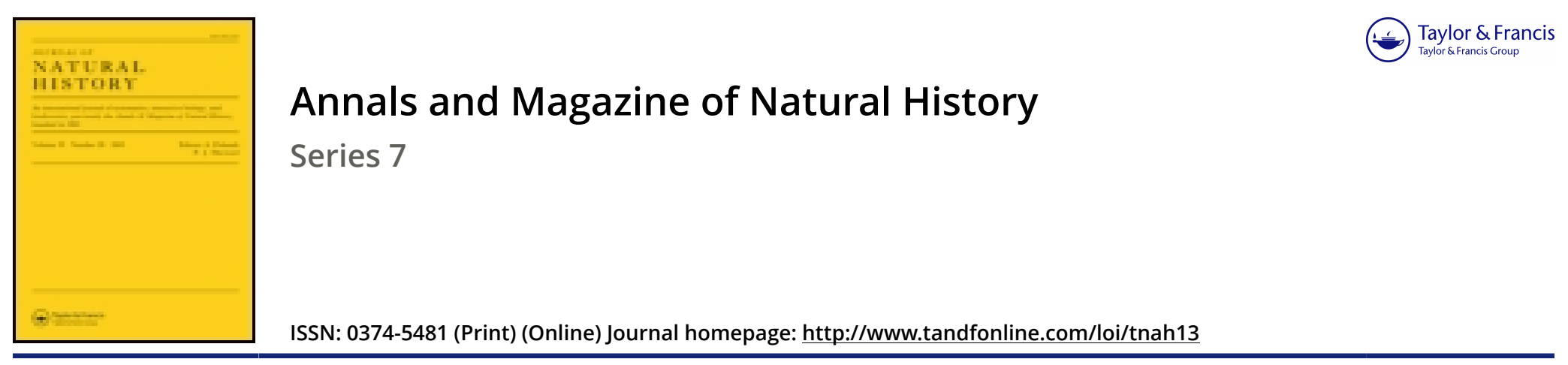

\title{
XLVII.-Descriptions of new fishes and reptiles discovered by Dr. F. Silvestri in South America
}

\section{G.A. Boulenger F.R.S.}

To cite this article: G.A. Boulenger F.R.S. (1902) XLVII._Descriptions of new fishes and reptiles discovered by Dr. F. Silvestri in South America, Annals and Magazine of Natural History, 9:52, 284-288, DOI: $10.1080 / 00222930208678587$

To link to this article: http://dx.doi.org/10.1080/00222930208678587

\section{曲 Published online: 28 Sep 2009.}

Submit your article to this journal

\section{山 Article views: 2}

\section{Q View related articles $\longleftarrow$}

Citing articles: 3 View citing articles 


\section{Vallentinia fallilandica, sp. n.}

Umbrella bell-shaped, about one and half times as high as broad.

Stomach short, about one third the length of the umbrellacavity, not situated on a peduncle.

Mouth with lips (four?).

Gonads situated on the radial canals in the upper half of the umbrella-cavity, a little way below the stumach; oval and sac-like.

Tentacles, four solid perradial with terminal suckers and twenty-four hollow tentacles (six in each quadrant, evenly distributed) with bands of nematocysts.

Sense-organs, sixteen vesicles enclosed inside the margin of the umbiella, each with a single otolith.

Size: 3 millim. in height and 2 millim. in width.

The collection contains only a single specimen.

'This species probably lives amongst the kelp.

University College, London, 13th February, 1902.

XLVII.-Descriptions of new Fishes and Reptiles discrvered by Dr. $F^{*}$. Silvestri in South America. By G. A. Boulenger, F.R.S.

THE new species here described are from a large collection formed by Dr. F. Silvestri in 1900 in Brazil, Paraguay, and Argentina, entrusted to me for study by the Director of the Genoa Civic Museum. Duplicates have been kept for the British Museum.

\section{Fishes.}

\section{Leporinus Silvestrii.}

Depth of body $3 \frac{1}{2}$ to $3 \frac{2}{3}$ times in total length, length of head 4 to $43_{3}^{1}$ times. Eye perfectly lateral, visible from above and from below, in the middle of the length of the head, its diameter 4 times in the length of the head, 2 to 21 in the interocular width; width of the mouth half that of the head; lips feebly fringed; teeth white. Dorsal II 10, a little nearer the root of the caudal than the end of the snout, its border convex, its longest ray $\frac{3}{4}$ the length of the head. Anal III 8. Pectoral $\frac{2}{3}$ the length of the head, terminating at a great distance from the ventral, which is a little longer *. Caudal

* The ventral fins are entirely absent in one of the specimens. 
forked. Caudal peduncle a little longer than deep. Scales $40-42 \frac{6 \frac{1}{2}-7 \frac{1}{2}}{77_{2}^{2}}, 6$ between the lateral line and the ventral fin. Olive above, whitish beneath; 7 or 8 darker cross-burs, ending in points on the sides of the ventral surface; three large round black sp its over these bars, the first below the dorsal fin, the third at the base of the caudal.

Total length 205 millim.

In the young ( 85 millim.) the depth of the body equals the length of the head and is contained $3 \frac{1}{2}$ times in the total, the diameter of the eye is $3 \frac{1}{2}$ times in the length of the head and $1 \frac{1}{2}$ in the interocular width, and the three round blask spots are proportionally larger.

Several specimens from the Rio Coxipo, M itto Groszo.

This species is most nearly allied to L. fusciatus, Bl., from which it differs in the somewhat shorter snout, the white teeth, and the coloration. L. Frederici, Bl., differs in having fewer scales in a vertical series.

\section{Parodon Gestri.}

Depth of body equal to length of head, 4 times in total length. Eye perfectly lateral, in the middle of the length of the head, its diameter $4 \frac{1}{2}$ times in the length of the head, $1 \frac{2}{3}$ in the interocular width; snout strongly projecting beyond the mouth; præmaxillary teeth 8 , as in P. suborbitalis, with 12 to 15 denticles, maxillaries and mandibulars 2 on each side. Dorsal III 9, a little nearer the root of the caudal fin than the end of the snout, its longest ray $\frac{3}{4}$ the length of the head. Anal II 7. Pectoral as long as the head, not reaching the base of the ventral; latter $\frac{3}{4}$ the length of the head, inserted under the second half of the dorsal. Caudal forked. Caudal peduncle as long as deep. Scales $35 \frac{42}{52}, 4$ between the lateral line and the root of the ventral. Olive above, whitish beneath; 15 dark vertical rhombs close together across the lateral line.

Total length 60 millim.

A single specimen from the Rio Coxipo, Matto Grosso.

This new species, which I have much pleasure in naming after Dr. R. Gestro, of the Genoa Civic Museum, comes near $P$. Hilarii, Reinhardt, trom which it differs in the shorter body, the more prominent snout, the position of the ventrals entirely below the dorsal, and the coloration.

\section{Curimatus nigrotenia.}

Depth of body equal to length of head, $3 \frac{1}{2}$ times in total Ann. \& Mag. N. Hist. Sicr. 7. Vol. ix. 
length. Snout shorter than the postocular part of the head, as long as the diameter of the eye, which is $3 \frac{1}{3}$ to $3 \frac{1}{2}$ times in the length of the head and $1 \frac{1}{4}$ to $1 \frac{1}{3}$ in the interorbital width; adipose eyelid moderately developed in front and behind. Belly rounded before and behind the ventrals. Dorsal II 10, a little nearer root of caudal than end of snout, its longest ray $\frac{1}{3}$ to $\frac{3}{4}$ the

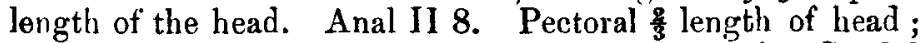
ventral below middle of dorsal. Caudal forked. Caudal peduncle a little longer than deep. Scales cycloid, 43-44 $\frac{7_{2}^{3}-8 \frac{1}{2}}{8}, 6$ between the lateral line and the base of the ventral. Brownish above, white beneath; a black band along the lateral line, extending on the middle rays of the caudal; fins unspotted.

Total length 60 millim.

Several specimiens from the Rio Coxipo, Matto Grosso.

Stands nearest to C. elegans, Stdr., but has more scales in a vertical series.

\section{Bunocephalus Dorio.}

Depth of head twice in its width, which is a little greater than its length; upper jaw not projecting; cranial ridges feebly prominent; interorbital space concave, half the width of the corresponding part of the head; maxillary barbel much longer than the head, extending nearly to the middle of the pectoral spine, posterior mandibular barbel only half as long and about once and a half the length of the anterior. Pectoral spine slightly curved, with strong serræ on the outer border, reaching the base of the ventral fin in the male, not so far in the female. Coracoid processes parallel, as long as their distance from each other, extending to the posterior third of the pectoral spine. Dorsal fin with 5 rays, equally distant from the end of the snout and the root of the caudal, or a little nearer the latter; first ray 3 the length of the head. Anal with 7 rays. Caudal peduncle compressed posteriorly, its length $4 \frac{1}{2}$ to $5 \frac{1}{2}$ times in the total. Skin granular, with larger tubercles forming longitudinal series on the caudal region. Dark brown above, with three blackish cross-bands, the first through the base of the dorsal fin, the two others on the caudal peduncle; dorsal fin black, whitish at the end; caudal black, whitish at the base and edged with white.

Total length 83 millim.

Five specimens from Villa Rica, Paraguay, and one from Posadas, Rio Parana.

This new species, which I have the privilege of naming in honour of the eminent Director of the Genoa Civic Museum, 
is most nearly related to B. bicolor, Stdr., which is readily distinguished by the shorter barbels and the longer caudal peduncle.

\section{REPTILES.}

\section{Amphisbcena Silvestrii.}

Snout rounded, prominent. Rostral large, pentagonal, visible from above; nasals forming a suture behind the rostral; a pair of large præfrontals and a pair of smaller frontals; suture between the præfrontals as long as that between the frontals and twice as long as that between the nasals; a pair of shields forming a short suture behind the frontals, followed by a pair of smaller shields forming a longer suture; eye distinct through the ocular, which is in contact with the second and third labials; no præucular; a square postocular; four upper labials, fourth small and separated from the postocular by one shield; symphysial tetragonal, followed by a large heptagonal median chin-shield; three lower labials, second largest; a large chin-shield on each side, just touching the median chin-shield and forming a suture with the second and third labials. 175 annuli on the body and 22 on the tail ; the segments of these aunuli longer than broad on the back, those of the two median ventral series twice to thrice as broad as long; on the middle of the body each annulus is formed of 22 segments, 10 above and 12 below the lateral grooves, which are perfectly distinct. Four anal segments; only two præanal pores. 'T'ail rounded at the end. Segments brown, edged with white, the white edge broader on the belly than on the back; end of snout and lower surface of head white.

Length to vent 130 millim.; tail 20 ; diameter of body 5 .

A single specimen of this very distinct species was obtained at Cuyaba.

\section{Philodryas subcarinatus.}

Diameter of eye 2 length of snout; latter rounded, feebly prominent. Rostral as deep as broad, its upper portion half as long as its distance from the frontal; internasals shorter than the profrontals; frontal once and a half as long as broad, a little longer than its distance from the end of the snout, shorter than the parietals; loreal a little longer than deep; one præocular, narrowly separated from the frontal; two postoculars ; temporals $1+3$; eight upper labials, fourth and fitth entering the eye; five lower labials in contact with the anterior chin-shields, which are longer than the posterior. 
Scales short, rounded behind, with two apical pits, faintly keeled on the back, in 21 rows. Ventrals rounded, 213 ; anal divided; subcaudals 114. Green above, white beneath; upper lip white.

Total length 255 millim.; tail 70.

A single young specimen from Colonia Benitez, Chaco.

This species is nearer to P. aestivus, Schleg., than to any other, but is easily distinguished from it by the blunter snout and the shorter, indistinctly keeled scales.

\section{XLVIIJ-Description of a new Barbus from Natal. By G. A. BuUlenger, F.R.S.}

Two species have been confounded in the original description of Barbus Gurntyi, Günther, Cat. Fish. vii. p. 102. The character of the small eye "its diameter being one-fifth of the length of the head in specimens only $3 \frac{1}{2}$ inches long," having been specially emphasized by the describer, it seems to me the proper course to restrict the name chosen by him to the emaller specimens, and to propose a new name for the larger ones which were believed to represent the adult condition. In doing this I have great pleasure in connecting the name of Col. Bowker with the fish of which he presented a young individual to the British Museum a few years ago, as it is through this that I was first able to detect the error which is here corrected.

\section{Barbus Boukeri.}

Depth of body nearly equal to length of head, $3 \frac{8}{4}$ to $4 \frac{1}{4}$ times in total length. Snout rounded, about $\frac{1}{3}$ length of head; diameter of eye $4 \frac{1}{2}$ (half-grown specimen) to $5 \frac{1}{2}$ times in length of head, $1 \frac{1}{3}$ to twice in interocular width; width of mouth more than half that of head; lips thick; two pairs of barbels, the posterior a little longer than the anterior and as long as or slightly longer than the eye. Dorsal III 8-9, equally distant from occiput and root of caudal, its border slightly concave; third ray feeble, smooth; longest ray 3 to 2. length of head. Anal II 5 ; longest ray $\frac{2}{3}$ to $\frac{3}{4}$ length of head, reaching or nearly reaching root of caudal. Pectoral $\frac{3}{4}$ to $\frac{4}{3}$ length of head, not reaching the ventral, which is inserted under the first rays of the dorsal. Caudal forked. Caudal peduncle $1 \frac{1}{2}$ to $1 \frac{2}{3}$ as long as deep. Scales $33-36 \frac{5 \frac{1}{2}-6 \frac{1}{2}}{5_{\frac{1}{2}}}, 2 \frac{1}{2}$ between lateral line and root of caudal. Olive-brown above, silvery beneath. 